\title{
Growth and carcass characteristics of crossbred progeny from lean-tailed and fat-tailed sheep breeds
}

\author{
M. Khaldari, N.E.J. Kashan", A. Afzalzadeh and A. Salehi \\ Animal Science Department, Abureyhan College of Agriculture, P.O. Box 11365-4117, Tehran, Iran
}

\begin{abstract}
The performance of two fat-tailed sheep breeds, Chaal and Zandi, and their F1 and R1 crossbred lambs from a lean-tailed breed, Zel, was compared. The weaned lambs from the Chaal and Zandi groups were finished over periods of 105 and 90 days, respectively, and body weight gain and feed consumption were recorded. Forty six male and female lambs from the six finishing groups were slaughtered. The weights of blood, internal organs, intestines before and after removal of digesta, head, feet, pelt and carcasses were recorded. The left sides of the carcasses were cut into six pieces. Individual joints were dissected into lean meat, bone, subcutaneous fat (SCF), intramuscular fat (IMF) and trimmings, and weighed separately. The fat surrounding the intestine and kidney was weighed and considered as internal fat. All the soft tissue (lean meat and fat) of the left sides of the carcasses was ground and representative samples were taken for chemical analyses. The differences of eye muscle (Longissimus dorsi) area $\left(\mathrm{cm}^{2}\right)$, and protein and bone percentages were not significant between both breeds and their crosses. In the R1 the fat-tail percentage was less than in the F1 and pure lambs of both breeds. In contrast, the SCF and IMF percentages were higher in all crossbred combinations. The internal fat percentages in crossbreds were higher, and in the Chaal group differed significantly from that of the pure lambs. The SCF/IMF ratio in the R1 lambs was lower than in the pure breds. This difference for Chaal crossbreds was significant. The lower ratio of SCF/IMF and the higher internal fat of crossbred lambs compared to pure breds showed that carcass quality of the crossbred was inferior compared to the pure bred lambs in terms of fat distribution in the body.
\end{abstract}

Keywords: Sheep, fat-tail, backcross, Chaal, Zandi, Zel

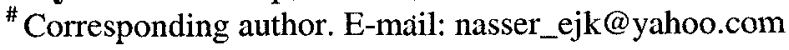

\section{Introduction}

In Iran all sheep breeds except the Zel breed are fat-tailed. The fat-tail is regarded as a survival mechanism of animals in hazardous environments and thus a valuable reserve for the animal during migration and dry winters (Kashan et al., 2005). In recent years there has been a tendency among farmers to raise their sheep in more intensive systems of production. Sheep are kept indoors and are fed harvested roughage and concentrates in the barn. In such a system the cost of feeding is high and farmers have to reduce cost by increasing the efficiency of the system. The amount of feed required to deposit fat in the fat tails of these breeds and the cost thereof could be high, while the trend in consumer preference is changing away from fat to lean meat. Reducing the size or removing the fat-tail of these sheep breeds can be an option for improving the efficiency of the system. This has been practiced by docking the fat tails (Donovan $e t a l$., 1973; Shelton et al., 1991) or crossing fat-tailed breeds with lean-tailed breeds (Kashan et al., 2005). Kashan et al. (2005) found that the percentage of fat-tail of F1 lambs from crosses between ewes of two fat-tailed breeds (Chaal and Zandi) and rams of the lean-tailed breed, Zel, was reduced by half compared to that of pure bred lambs. However, the percentage of subcutaneous and intramuscular fat was higher. It is hypothesized that the size of the fat-tail and total body fat would be lower in lambs with a higher percentage of genes from a lean-tailed breed than from a fat-tailed breed. The objective of the present study was to compare the efficiency of live weight gain and carcass quality of pure Chaal and Zandi lambs, their F1 crosses (Zel x Chaal and Zel x Zandi) and from backcrosses of F1 lambs with Zel rams (R1).

\section{Materials and Methods}

This study was conducted at the Research Station of the Abureyhan College of Agriculture, Tehran University, Iran. Ewes from two flocks of 70 and 80 ewes of the Chaal and Zandi breeds, respectively, were 
randomly divided into two groups. In each breed, one group was mated with rams of the same breed and the other group with Zel rams. In addition, there were $15 \mathrm{Zel} x$ Chaal and $15 \mathrm{Zel} \times$ Zandi crossbred (F1) ewes that were backcrossed with Zel rams to produce the second cross (R1) lambs. The birth dates of lambs ranged from 10 February to 20 March 2003 . The lambs were reared with their dams until an average age of 90 days. After weaning, 46 lambs ( 23 male and 23 female) were balanced for age and weight and randomly allocated to six treatment groups in a finishing trial. The number of Chaal, Zandi, Zel $x$ Chaal, Zel $x$ Zandi, Rll of Chaal and R1 of Zandi lambs was 9, 9, 9,9,5 and 5 heads, respectively. Two weeks prior to the start of this trial, the lambs were treated against internal and external parasites.

The finishing diet consisted of $40 \%$ lucerne, $40 \%$ barley, $10 \%$ cottonseed meal and $10 \%$ straw. The feed was offered twice a day ad libitum. During the finishing period, the lambs were weighed once every 15 days. The quantity of feed required for each group in one week was weighed at the start of the week. Every morning before feeding, feed left from the previous day was collected and weighed back, and weekly consumptions were determined. According to the literature the mature size of the Zandi breed is less than that of the Chaal. Therefore, the duration of the finishing period for pure and crossbred lambs of the Zandi and Chaal groups was set at 90 and 105 days, respectively. At the end of the finishing period the lambs were weighed and slaughtered. The weights of the blood, internal organs, intestine before and after removal of digesta, head, feet, pelt and carcasses were recorded. The carcasses were chilled at $4{ }^{\circ} \mathrm{C}$ for $24 \mathrm{~h}$. The carcasses were then split along the spinal cord into two halves. The left side of the carcasses was cut into six pieces (neck, shoulder, brisket, loin, legs and fat-tail) and weighed. The individual joints were dissected into lean meat, bone, subcutaneous fat (SCF), intramuscular fat (IMF) and trimmings, and weighed. The fat surrounding the intestine and kidney was weighed and considered as internal fat. Soft tissue (lean meat and fat) from the left side of the carcass was ground by passing it twice through a plate with a $4 \mathrm{~mm}$ orifice. Representative samples were taken for determination of dry matter (DM), crude protein, ash and chemical fat (ether extract) contents, using AOAC (1990) procedures.

The mathematical model for the analysis of growth performance, offal, commercial joints and carcass of each breed group included fixed effects due to lamb breed, sex (male, female), first order interactions and residual error (Harvey, 1990). The basic breed groups were analysed separately and were pure Chaal and Zel $x$ Chaal and Zel x (Zel x Chaal) crosses, and pure Zandi and Zel x Zandi and Zel x (Zel x Zandi) crosses.

Initial weights of the lambs were used as co-variates for the slaughter weights and average daily gains. The empty body weight was used as a co-variate for the offal and cold carcass weight. The cold carcass weight was used as a co-variate for the carcass components.

\section{Results and Discussion}

The means of growth performance, weight of offal parts and chemical composition and components of the carcasses of the Zandi breed are presented in Table 1. In comparison the male lambs had significantly heavier slaughter weights $(39.6$ vs. $34.8 \mathrm{~kg})$ and empty body weights $(34.6 \mathrm{vs} .28 .0 \mathrm{~kg})$ than the female lambs. The percentages of SCF, IMF, fat-tail, carcass fat and internal fat in males were 19.0, 4.0, 8.3, 31.4 and $6.3 \%$ and in females $19.7,5.5,6.8,32.0$ and $9.2 \%$, respectively. Differences were not significant, except for internal fat.

The dressing percentages of Zandi, F1 and R1 lambs on the basis of empty body weights were 53.8, 54.0 and $55.4 \%$, respectively. Estimates in the literature for dressing percentages on empty body weight basis for the Zandi and Zel x Zandi cross were 58.2 and 53.2\% (Nik-khah, 1992; Kyanzad, 2001; Kashan, 2005). The feed conversion ratio ( $\mathrm{kg}$ feed $/ \mathrm{kg}$ weight gain) was not available for individual animals due to group feeding. The calculated values showed that the value for crossbreds was higher than for the pure Zandi. Feed conversion ratios of $7.9-8.9$ for the Zandi and 7.9 for the Zel $x$ Zandi cross have been reported (Kashan, 1993; 2005). Differences of protein, lipid, bone, carcass fat, internal fat percentage and the ratio of lean/fat and SCF/IMF in the three groups within breed were not significant $(\mathrm{P}>0.05)$. However, in the Zandi breed the fat-tails as a percentage of the carcass were lower $(\mathrm{P}<0.05)$ and the SCF, MMF higher $(\mathrm{P}<0.05)$ in crosses than in the pure bred lambs. The weights of the heart and lungs of crossbred lambs were higher than that of the purebred lambs $(\mathrm{P}<0.05)$.

Kashan et al. (2005) reported that after a 114 day finishing period the percentages of lean meat, lipid, fat-tail, SCF, IMF for pure Zandi lambs were 45.4, 36.9, 15.8, 3.0 and 1.7\%, respectively and in Zel x Zandi 
crosses $47.5,33.0,7.5,3.7$ and $1.9 \%$, respectively. In the present study the finishing period lasted 90 days, which could be a possible reason for the lower carcass fat percentage of these lambs.

Table 1 Least square mean ( \pm s.e.) of growth, carcass composition and components of the Zandi group

\begin{tabular}{|c|c|c|c|c|c|}
\hline & \multicolumn{3}{|c|}{ Breed } & \multicolumn{2}{|c|}{ Sex } \\
\hline & Zandi & $\begin{array}{c}\text { Zel } \times \text { Zandi } \\
(\mathrm{F} 1)\end{array}$ & $\begin{array}{c}\text { Zel x } \\
\text { (Zel x Zandi) }\end{array}$ & Male & Female \\
\hline \multicolumn{6}{|l|}{ Growth performance $(\mathrm{kg})$} \\
\hline Starting weight & $22.9 \pm 1.1$ & $24.1 \pm 1.0$ & $21.3 \pm 1.4$ & $23.9 \pm 0.9$ & $21.6 \pm 1.0$ \\
\hline Slaughter weight & $36.3 \pm 0.8$ & $36.9 \pm 0.8$ & $38.4 \pm 1.1$ & $39.6^{a} \pm 0.7$ & $34.8^{b} \pm 0.8$ \\
\hline Empty body weight & $30.8 \pm 1.2$ & $32.5 \pm 1.2$ & $30.6 \pm 1.6$ & $34.6^{a} \pm 1.0$ & $28.0^{b} \pm 1.2$ \\
\hline Cold carcass weight & $17.1 \pm 0.2$ & $17.2 \pm 0.2$ & $17.4 \pm 0.3$ & $17.1 \pm 0.2$ & $17.4 \pm 0.3$ \\
\hline Cold dressing percentage & $53.8 \pm 0.7$ & $54.0 \pm 0.7$ & $55.4 \pm 1.0$ & $53.8 \pm 0.7$ & $55.0 \pm 0.9$ \\
\hline Feed conversion ratio* & 8.0 & 8.4 & 8.5 & - & - \\
\hline \multicolumn{6}{|l|}{ Offal parts (kg) } \\
\hline Pelt & $4.8 \pm 0.2$ & $4.3 \pm 0.2$ & $4.3 \pm 0.2$ & $4.7 \pm 0.2$ & $4.3 \pm 0.2$ \\
\hline Heart & $0.172 \pm 0.01$ & $0.201 \pm 0.009$ & $0.194 \pm 0.013$ & $0.205^{\mathrm{a}} \pm 0.008$ & $0.172^{b} \pm 0.009$ \\
\hline Liver & $0.54 \pm 0.02$ & $0.56 \pm 0.02$ & $0.62 \pm 0.03$ & $0.61 \pm 0.02$ & $0.54 \pm 0.03$ \\
\hline Kidney & $0.118 \pm 0.008$ & $0.112 \pm 0.007$ & $0.104 \pm 0.01$ & $0.121 \pm 0.006$ & $0.101 \pm 0.007$ \\
\hline Lung & $0.45^{\mathrm{a}} \pm 0.02$ & $0.55^{b c} \pm 0.02$ & $0.59^{c} \pm 0.03$ & $0.56 \pm 0.02$ & $0.50 \pm 0.03$ \\
\hline Eye muscle ${ }^{* *}$ area $\left(\mathrm{cm}^{2}\right)$ & $15.9 \pm 0.8$ & $14.1 \pm 0.7$ & $12.9 \pm 1.0$ & $13.5 \pm 0.75$ & $15.2 \pm 0.9$ \\
\hline \multicolumn{6}{|c|}{ Chemical composition (Fresh basis) \% } \\
\hline Water & $49.9 \pm 0.3$ & $50.0 \pm 0.3$ & $50.3 \pm 0.4$ & $50.1 \pm 0.3$ & $50.1 \pm 0.3$ \\
\hline Protein & $15.1 \pm 0.4$ & $15.3 \pm 0.4$ & $15.1 \pm 0.5$ & $15.1 \pm 0.3$ & $15.3 \pm 0.4$ \\
\hline Lipid & $33.0 \pm 0.5$ & $32.6 \pm 0.5$ & $32.1 \pm 0.7$ & $32.7 \pm 0.4$ & $32.5 \pm 0.5$ \\
\hline Ash & $1.1 \pm 0.04$ & $1.0 \pm 0.04$ & $0.99 \pm 0.05$ & $1.0 \pm 0.03$ & $1.03 \pm 0.04$ \\
\hline \multicolumn{6}{|l|}{ Carcass component $(\mathrm{kg})$} \\
\hline Lean meat & $8.4^{a} \pm 0.2$ & $9.1^{b c} \pm 0.2$ & $9.3^{c} \pm 0.3$ & $9.3^{\mathrm{a}} \pm 0.2$ & $8.6^{b} \pm 0.2$ \\
\hline Bone & $2.9 \pm 0.1$ & $2.8 \pm 0.1$ & $2.7 \pm 0.1$ & $2.8 \pm 0.1$ & $2.8 \pm 0.1$ \\
\hline Subcutaneous fat (SCF) & $2.9^{a} \pm 0.1$ & $3.3^{a b} \pm 0.1$ & $3.7^{b} \pm 0.2$ & $3.2 \pm 0.1$ & $3.5 \pm 0.2$ \\
\hline Intramuscular fat (IMF) & $0.6^{\mathrm{a}} \pm 0.1$ & $0.9^{b c} \pm 0.1$ & $0.87^{\mathrm{c}} \pm 0.1$ & $0.68^{\mathrm{a}} \pm 0.1$ & $0.9^{b} \pm 0.1$ \\
\hline Fat-tail & $2.3^{a} \pm 0.2$ & $1.0^{\mathrm{bc}} \pm 0.2$ & $0.64^{\mathrm{c}} \pm 0.2$ & $1.4 \pm 0.2$ & $1.2 \pm 0.2$ \\
\hline Carcass fat & $5.8 \pm 0.2$ & $5.0 \pm 0.2$ & $5.2 \pm 0.3$ & $5.2 \pm 0.2$ & $5.6 \pm 0.2$ \\
\hline Internal fat & $1.2 \pm 0.3$ & $1.4 \pm 0.12$ & $1.5 \pm 0.2$ & $1.0^{\mathrm{a}} \pm 0.12$ & $1.6^{b} \pm 0.15$ \\
\hline Total body fat & $7.0 \pm 0.3$ & $6.6 \pm 0.3$ & $6.7 \pm 0.4$ & $6.2^{\mathrm{a}} \pm 0.3$ & $7.3^{b} \pm 0.3$ \\
\hline Lean/ bone ratio & $2.9^{\mathrm{ab}} \pm .12$ & $3.2 \pm 0.11$ & $3.5^{b} \pm 0.15$ & $3.3 \pm 0.11$ & $3.1 \pm 0.11$ \\
\hline Lean/fat ratio & $1.5 \pm 0.1$ & $1.8 \pm 0.1$ & $1.8 \pm 0.13$ & $1.8 \pm 0.1$ & $1.6 \pm 0.1$ \\
\hline $\mathrm{SCF} / \mathrm{IMF}$ & $4.9 \pm 0.4$ & $3.8 \pm 0.4$ & $4.6 \pm 0.5$ & $5.0^{\mathrm{a}} \pm 0.3$ & $3.8^{b} \pm 0.4$ \\
\hline \multicolumn{6}{|l|}{ Carcass component (\%) } \\
\hline Lean meat & $50.3 \pm 1.3$ & $53.0 \pm 1.2$ & $55.4 \pm 1.6$ & $53.8 \pm 1.0$ & $51.9 \pm 1.2$ \\
\hline Bone & $17.3 \pm 0.4$ & $16.7 \pm 0.4$ & $16.0 \pm 0.5$ & $16.3 \pm 0.3$ & $17.0 \pm 0.4$ \\
\hline Subcutaneous fat & $17.0^{a} \pm 0.9$ & $19.2^{\mathrm{ab}} \pm 0.9$ & $22.0^{b} \pm 1.2$ & $19.0 \pm 0.7$ & $19.7 \pm 0.9$ \\
\hline Intramuscular fat & $3.6^{a} \pm 0.3$ & $5.4^{b c} \pm 0.3$ & $5.3^{\mathrm{c}} \pm 0.5$ & $4.0 \pm 0.3$ & $5.5 \pm 0.3$ \\
\hline Fat-tail & $13.1^{2} \pm 0.9$ & $6.0^{b c} \pm 0.9$ & $3.6^{c} \pm 0.2$ & $8.3 \pm 0.7$ & $6.8 \pm 0.9$ \\
\hline Carcass fat & $33.6 \pm 0.3$ & $30.7 \pm 0.2$ & $30.8 \pm 0.2$ & $31.4 \pm 0.2$ & $32.0 \pm 0.2$ \\
\hline Internal fat & $7.1 \pm 0.7$ & $8.2 \pm 0.7$ & $7.9 \pm 0.9$ & $6.3^{a} \pm 0.6$ & $9.2^{b} \pm 0.7$ \\
\hline
\end{tabular}

\footnotetext{
${ }_{\mathrm{a}-\mathrm{c}}$ within breed and within sex within rows different superscripts signify differences at $\mathrm{P}<0.05$
}

* $\mathrm{kg} \mathrm{feed/kg} \mathrm{gain;} \mathrm{**} \mathrm{Longissimus} \mathrm{dorsi}$ 
The means of growth performance, weight of offal parts, chemical composition and components of the carcasses of the Chaal breed are presented in Table 2. Male lambs had significantly heavier slaughter weights (41.9 vs. $36.8 \mathrm{~kg})$, and empty body weights $(36.7$ vs. $29.4 \mathrm{~kg})$ than the female lambs. The percentages of SCF and internal fat in the males were 16.3 and $4.9 \%$ and in the females 20.1 and $4.7 \%$, respectively $(\mathrm{P}<0.01)$.

Table 2 Least square mean ( \pm s.e.) of growth, carcass composition and components of the Chaal group

\begin{tabular}{|c|c|c|c|c|c|}
\hline & \multicolumn{3}{|c|}{ Breed } & \multicolumn{2}{|c|}{ Sex } \\
\hline & Chaal & Zel x Chaal (F1) & $\begin{array}{c}\text { Zel x } \\
\text { (Zel x Chaal) }\end{array}$ & Male & Female \\
\hline \multicolumn{6}{|l|}{ Growth performance (kg) } \\
\hline Start weight & $24.3 \pm 1.2$ & $23.4 \pm 1.2$ & $24.1 \pm 1.6$ & $25.5 \pm 1.0$ & $22.4 \pm 1.7$ \\
\hline Slaughter weight & $39.0 \pm 0.5$ & $38.9 \pm 0.5$ & $40.2 \pm 0.7$ & $41.9^{a} \pm 0.5$ & $36.8^{b} \pm 0.5$ \\
\hline Empty body weight & $33.0 \pm 1.3$ & $32.0 \pm 1.3$ & $34.2 \pm 1.7$ & $36.7^{a} \pm 1.1$ & $29.4^{b} \pm 1.3$ \\
\hline Cold carcass weight & $18.7 \pm 0.14$ & $18.6 \pm 0.14$ & $18.3 \pm 0.19$ & $18.1^{a} \pm 0.15$ & $19.0^{b} \pm 0.17$ \\
\hline Cold dressing percentage & $56.0 \pm 0.7$ & $55.6 \pm 0.7$ & $54.4 \pm 0.9$ & $55.2 \pm 0.6$ & $55.5 \pm 0.7$ \\
\hline Feed conversion ratio & 8.3 & 8.5 & 8.6 & - & - \\
\hline \multicolumn{6}{|l|}{ Offal parts $(\mathrm{kg})$} \\
\hline Pelt & $4.9 \pm 0.17$ & $4.4 \pm 0.18$ & $4.3 \pm 0.2$ & $4.6 \pm 0.19$ & $4.5 \pm 0.2$ \\
\hline Heart & $0.139^{a} \pm 0.004$ & $0.151^{b} \pm 0.004$ & $0.173^{c} \pm 0.005$ & $0.153 \pm 0.004$ & $0.156 \pm 0.005$ \\
\hline Liver & $0.56 \pm 0.02$ & $0.58 \pm 0.02$ & $0.65 \pm 0.03$ & $0.65^{\mathrm{a}} \pm 0.02$ & $0.55^{b} \pm 0.03$ \\
\hline Kidney & $0.107 \pm 0.005$ & $0.112 \pm 0.005$ & $0.128 \pm 0.007$ & $0.127^{a} \pm 0.004$ & $0.103^{b} \pm 0.005$ \\
\hline Lung & $0.41^{\mathrm{a}} \pm 0.02$ & $0.49^{b} \pm 0.02$ & $0.49^{b} \pm 0.03$ & $0.46 \pm 0.02$ & $0.46 \pm 0.03$ \\
\hline Eye muscle area $\left(\mathrm{cm}^{2}\right)$ & $16.6 \pm 0.98$ & $19.4 \pm 0.98$ & $19.3 \pm 1.3$ & $18.2 \pm 0.8$ & $18.7 \pm 0.97$ \\
\hline \multicolumn{6}{|c|}{ Chemical composition (fresh basis) \% } \\
\hline Water & $49.0^{\mathrm{a}} \pm 0.3$ & $49.9^{b} \pm 0.3$ & $50.7^{b} \pm 0.4$ & $49.8 \pm 0.2$ & $49.9 \pm 0.3$ \\
\hline Protein & $15.5 \pm 0.3$ & $15.9 \pm 0.3$ & $15.1 \pm 0.4$ & $15.6 \pm 0.3$ & $15.4 \pm 0.3$ \\
\hline Lipid & $33.8^{\mathrm{a}} \pm 0.5$ & $31.9^{b} \pm 0.9$ & $32.5^{b} \pm 0.6$ & $32.4 \pm 0.4$ & $33.2 \pm 0.5$ \\
\hline Ash & $1.0 \pm 0.03$ & $0.97 \pm 0.02$ & $0.99 \pm 0.04$ & $0.99 \pm 0.02$ & $0.98 \pm 0.03$ \\
\hline \multicolumn{6}{|l|}{ Carcass component $(\mathrm{kg})$} \\
\hline Lean meat & $10.11 \pm 0.4$ & $9.9 \pm 0.4$ & $9.4 \pm 0.5$ & $9.8 \pm 0.4$ & $9.8 \pm 0.4$ \\
\hline Bone & $2.9 \pm 0.1$ & $2.7 \pm 0.1$ & $2.7 \pm 0.14$ & $2.9 \pm 0.1$ & $2.6 \pm 0.1$ \\
\hline Subcutaneous fat (SCF) & $2.9^{a} \pm 0.2$ & $3.6^{\mathrm{b}} \pm 0.2$ & $3.8^{\mathrm{b}} \pm 0.3$ & $3.4 \pm 0.2$ & $3.5 \pm 0.2$ \\
\hline Intramuscular fat (IMF) & $0.61^{a} \pm 0.06$ & $0.96^{\mathrm{b}} \pm 0.06$ & $1.4^{\mathrm{c}} \pm 0.09$ & $1.1^{\mathrm{a}} \pm 0.05$ & $0.87^{b} \pm 0.06$ \\
\hline Fat-tail & $2.2^{a} \pm 0.13$ & $0.98^{b} \pm 0.13$ & $0.90^{b} \pm 0.2$ & $1.6 \pm 0.1$ & $1.1 \pm 0.1$ \\
\hline Carcass fat & $5.6 \pm 0.3$ & $5.7 \pm 0.3$ & $6.1 \pm 0.4$ & $5.7 \pm 0.3$ & $5.9 \pm 0.3$ \\
\hline Internal fat & $0.79^{a} \pm 0.14$ & $1.3^{b} \pm 0.14$ & $1.8^{b} \pm 0.19$ & $0.75^{a} \pm 0.15$ & $1.8^{b} \pm 0.17$ \\
\hline Total body fat & $6.4^{a} \pm 0.3$ & $6.9^{\mathrm{ab}} \pm 0.3$ & $7.9^{b} \pm 0.4$ & $6.4^{\mathrm{a}} \pm 0.3$ & $7.7^{b} \pm 0.4$ \\
\hline Lean/ bone ratio & $3.5 \pm 0.18$ & $3.6 \pm 0.18$ & $3.5 \pm 0.2$ & $3.5 \pm 0.15$ & $3.6 \pm 0.18$ \\
\hline Lean/fat ratio & $1.8 \pm 0.14$ & $1.7 \pm 0.14$ & $1.5 \pm 0.18$ & $1.8 \pm 0.11$ & $1.6 \pm 0.13$ \\
\hline SCF/IMF & $4.9^{\mathrm{a}} \pm 0.3$ & $3.7^{b c} \pm 0.3$ & $3.0^{\mathrm{c}} \pm 0.4$ & $3.7 \pm 0.2$ & $4.1 \pm 0.3$ \\
\hline \multicolumn{6}{|l|}{ Carcass components $(\%)$} \\
\hline Lean meat & $52.2 \pm 1.6$ & $50.4 \pm 1.6$ & $49.3 \pm 2.2$ & $52.3 \pm 1.4$ & $49.0 \pm 1.6$ \\
\hline Bone & $15.2 \pm 0.5$ & $14.3 \pm 0.6$ & $14.2 \pm 0.7$ & $15.0 \pm 0.5$ & $14.1 \pm 0.5$ \\
\hline Subcutaneous fat & $14.6^{\mathrm{a}} \pm 1.1$ & $19.7^{\mathrm{bc}} \pm 1.1$ & $20.4^{\mathrm{c}} \pm 1.5$ & $16.3^{a} \pm 1.0$ & $20.1^{b} \pm 1.1$ \\
\hline Intramuscular fat & $3.1^{2} \pm 0.3$ & $5.4^{b} \pm 0.3$ & $7.1^{c} \pm 0.4$ & $5.2 \pm 0.3$ & $5.1 \pm 0.3$ \\
\hline Fat-tail & $11.2^{a} \pm 0.6$ & $5.5^{b c} \pm 0.6$ & $3.2^{\mathfrak{c}} \pm 0.8$ & $7.7 \pm 0.5$ & $6.6 \pm 0.6$ \\
\hline Carcass fat & $30.7 \pm 1.5$ & $31.6 \pm 1.5$ & $33.0 \pm 2.0$ & $29.8 \pm 1.3$ & $33.7 \pm 1.5$ \\
\hline Internal fat $(\%)$ & $3.2^{\mathrm{a}} \pm 0.8$ & $5.0^{b} \pm 0.8$ & $7.53^{\mathrm{c}} \pm 1.1$ & $4.9 \pm 0.7$ & $4.7 \pm 0.8$ \\
\hline
\end{tabular}

${ }^{a-c}$ means within a row and each of breed and sex effects not followed by the same subscript differ $(\mathrm{P}<0.05)$ 
The dressing percentages of Chaal, F1 and R1 lambs on the basis of empty body weight were 56.0, 55.6 and $54.4 \%$, respectively. Reported dressing percentages on empty body weight basis for the Chaal, Zel and Zel x Chaal breeds are 53.5, 51.5 and 50.1\%, respectively (Kashan, 1993; 2005; Maghsudi Nejad et al., 1996; Kyanzad, 2001). The feed conversion ratio in crossbreds seems to be higher than of the pure Chaal. Reports in the literature indicated feed conversion ratios $(\mathrm{kg}$ feed $/ \mathrm{kg}$ gain) for Chaal to be 7.4 and 8.3 (Kashan, 1993; 2005; Kyanzad, 2001) and 7.8 for the Zel x Chaal cross (Kashan, 2005).

The differences of protein, bone, lean meat, carcass fat percentages and the ratio of lean/fat in the three groups within a breed did not differ significantly $(\mathrm{P}>0.05)$. However, among the Chaal lambs the percentage of fat-tail in crosses was lower and the SCF, IMF higher than in the pure breds $(\mathrm{P}<0.05)$. The weights of the heart and lungs in crossbred lambs were higher than of the pure bred lambs $(\mathrm{P}<0.05)$.

The main objective of this study was to investigate the effect of crossing a lean-tailed breed with fat tailed breeds to determine the effects on performance and carcass quality of their crossbred lambs. The fattail percentages in F1 and R1 lambs of the Zandi group were 54.2 and $72.5 \%$ lower $(P<0.01)$, and in the Chaal group 50.1 and $71.5 \%$ lower $(\mathrm{P}<0.01)$ than in the respective pure bred lambs. However, the fat depots in the other parts of the body compensated for most of these relative reduction of fat-tail percentages in the crossbreds. Therefore, the differences in carcass fat (SCF, IMF and fat-tail) percentage between pure and crossbred lambs of both groups were not significant $(\mathrm{P}>0.05)$. Total body fat (carcass fat and internal fat) in pure, F1 and R1 lambs of the Zandi group was 40.7, 38.9 and $38.7 \%$, respectively and in the Chaal group $33.9,36.6$ and $40.5 \%$, respectively.

In the F1 and R1 lambs of the Zandi group the percentage of subcutaneous fat was respectively 13.8 and $28.0 \%$ higher $(\mathrm{P}<0.01)$ than in the pure Zandi lambs, and in Chaal group 24.0 and $31.0 \%$ higher $(\mathrm{P}<$ 0.01 ) than in the pure lambs. Percentage of internal fat in F1 and R1 lambs of the Chaal group was higher than in the pure lambs $(P<0.05)$. A decrease of fat-tail and an increase of SCF, IMF and internal fat percentages in crossbred lambs are in agreement with Kyanzad (2001), who found total SCF and IMF to be 16.6 and $20.1 \%$ in Chaal, 6.6 and $27.5 \%$ in Zel $x$ Chaal and 1.9 and $27.3 \%$ in pure Zel lambs, respectively. It is clear that in spite of the lower fat-tail percentage in the R1 lambs (relative to the F1 lambs), fat deposition in the other parts was higher. There was consequently no advantage in the F1 over pure bred animals in terms of different aspects of performance and carcass quality.

The present data showed that in spite of lower fat-tail percentages in crossbred lambs, none of the two cross combinations was superior in terms of economically important traits such as average daily gain, lean meat and lean to fat ratio. The percentage of internal fat in crossbreds, compared to the pure lambs was higher $(50-100 \%)$ and SCF/IMF ratio lower $(25-40 \%)$, which suggests that the carcass quality of crossbreds is inferior to that of the pure breeds.

\section{Conclusion}

It can be concluded that the Zel breed should neither be used as a terminal sire in a crossbreeding program, nor for synthesis of a new breed with the aim of reducing the size of the fat-tail.

\section{References}

AOAC, 1990. Official Methods of Analysis (15th ed). Association of Official Analytical Chemicals, Washington, D.C., USA.

Bicer, O., Pekel, E. \& Guney, O., 1984. Effects of docking on growth performance and carcass characteristic of fat-tailed Awassi ram lambs. Small Rumin. Res. 8, 353-357.

Donovan, P.B.O., Ghadaki, M.B., Beheshti, R.D. \& Salehi, B.A., 1973. Performance and carcass composition of docked and control fat-tailed Kellakui lambs. Anim. Prod. 16, 67-76.

Harvey, W.R., 1990. Mixed Model Least-squares and Maximum Likelihood Computer Program. PC-2 Version 4255. Mumford Drive, Colombus, O.H., USA.

Kashan, N., 1993. Motale-e khosusiat-e parvari va lasheh barehaye dou nejad goosfand chaal va zandi va amikhteh anha (Study of growth and carcass quality of Chaal and Zandi sheep breeds and crossbred lambs). Majaleh-e Olum-e Keshavarzi iran 24, 47-63 (in Persian).

Kashan, N., Alipanah, M. \& Eghbaleh, A., 1997. Barresi acidhay-e-charb dar donbeh charbi ahshai va goosht she nejad goosfand donbehdar-e irani (Study of fatty acids in tail fat, internal fat and meat of three fat- 
tailed Iranian sheep). First Sheep and Goat Congress Animal Science Research Institute, Karaj, Iran. pp. 223-230.

Kashan, N.E.J., Manafi Azar, G.H., Afzalzadeh, A. \& Salehi, A., 2005. Growth performance and carcass quality of finishing lambs from fat-tailed and tailed sheep breeds. Small Rumin. Res. 60, 267-271.

Kyanzad, M.R., 2001. Crossbreeding of the three Iranian sheep breeds with emphasis on growth and carcass characteristics of the lambs. Ph.D. thesis. University of Utra, Malaysia.

Maghsudi nejad, G.H., Rezai, M., Sajjadi, B. \& Jafari, K., 1996. Barresi-e asar-e sen va jens barehay-e zel-e mazanderan bar tavan-e parvari va khosusiat-e lasheh (Study of age and sex effects on growth performance and carcass characteristics of Mazanderan Zel sheep breed) pajuhesh va sazandegi 37,9799 (in Persian).

McClinton, O.W. \& Carson, A.F., 2000. Growth and carcass characteristics of three lamb genotypes finished on the same level of feeding. Anim. Sci. 70, 51-61.

Nik-khah, A., 1992. Darsad-e charbi-e ghabel-e joda kardan dar lashehgusfandan-e irani dar moghayeseh da gusfandan-e khareji (Comparison of carcass fat percentage of native and tailed European sheep breeds) Omur-e dam va abzian. Vijeh-e tabestan, 136-149.

Shelton, M., 1950. The hygienic system. In: Fasting and Sun Bathing. Vol. III, third ed. San Antonio, TX, USA.

Shelton, M., 1990. Influence of docking fat-tail (Karakul) sheep on lamb production. Small Rumin. Res. 3, 73-76.

Shelton, M., Willingham, T., Thompson, P. \& Roberts, E.M., 1991. Influence of docking and castration on growth and carcass traits of fat-tailed karakul, Rambouillet and crossbred lambs. Small Rumin. Res. 4, 235-243. 